\title{
A Flawed Solution to the Sex OfFender Situation IN THE UNITED STATES: THE LEGALITY OF CHEMICAL CASTRATION FOR SEX OFFENDERS
}

\author{
Matthew V. Daley*
}

TABLE OF CONTENTS

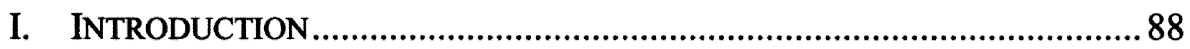

II. THE EVOLUTION AND HISTORY OF CASTRATION ………......................8

III. DEPO-PROVERA: THE LATEST METHOD OF CHEMICAL

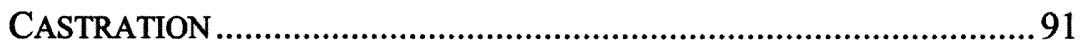

A. How Depo-Provera Works ....................................................... 91

B. The Side-Effects of Depo-Provera................................................ 92

C. Depo-Provera's Limitations: How They Affect Any Potential

Statutory Implementations .......................................................... 93

IV. ChEMICAL CASTRATION: THE CONSTITUTIONAL IMPLICATIONS..........94

A. Eighth Amendment Problems ...................................................... 94

1. Is Chemical Castration Treatment or Punishment?............... 94

2. Is Chemical Castration Cruel and Unusual Punishment? ....98

3. The Issue of Consent .......................................................... 101

B. The Equal Protection Claim..................................................... 102

1. The Strict Scrutiny Standard and Its Requirements ............ 102

2. The Intermediate Scrutiny Argument in Regards to Chemical Castration

3. Rational Basis Review: Its Result When Applied to Chemical Castration.

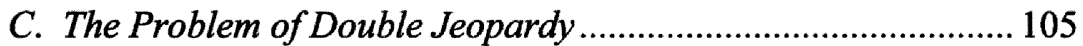

V. CURRENT STATE STATUTES AND THEIR INHERENT FLAWS .................... 106

A. California's Chemical Castration Statute ...................................106

B. Montana's Chemical Castration Statute .....................................109

C. Florida's Chemical Castration Statute ....................................... 112

D. Louisiana's Chemical Castration Statute ................................... 114

E. Oregon's Chemical Castration Statute ……………..................117

F. Overall Problems with the Chemical Castration

Statutes Now in Effect ................................................................ 119

G. Europe's Approach to Chemical Castration.............................. 120

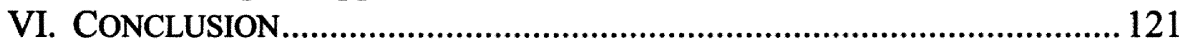

* J.D. Candidate, 2008, Indiana University School of Law - Indianapolis; B.S., 2005, Indiana University - Bloomington. 


\section{INTRODUCTION}

Prisons in the United States are being inundated with new prisoners at an alarming rate. Indeed, in some cases the influx of prisoners is so great that many prisons are either becoming full or dangerously overcrowded. Given the severe overcrowding facing prisons today, state and federal governments are under enormous pressure to find a way to provide relief for the system while still keeping truly dangerous criminals from being released back into society. One way governments are addressing the problem is by tackling recidivism. Recidivism occurs when an inmate, after being released from prison, commits another crime or perhaps even the same type of crime, is rearrested, and placed back in jail.

Almost all categories of crimes have a problem of recidivism, including crimes involving sex offenders. One study found that child molesters had a $36.9 \%$ recidivism rate while rapists had a $46.2 \%$ rate nationally. ${ }^{1}$ This means that more than one in three child molesters will commit a crime again while close to half of all rapists will commit another crime upon being released. In efforts to try to reduce this number, states have instituted a plethora of options. One of the most popular options is the civil commitment of sex offenders upon their release. ${ }^{2}$ This option keeps dangerous sex offenders off the streets and eliminates the risk that they will re-offend. However, aside from the constitutional problems inherent in such a solution, the cost is extremely high. ${ }^{3}$ It costs on average $\$ 26,000$ a year to keep someone in prison, while it costs on average over $\$ 100,000$ a year to civilly commit a sex offender under this concept. ${ }^{4}$ This high cost, along with the increasingly over-crowded status of prisons, has increased the pressure placed on government agencies to keep sex offenders from becoming recidivists while at the same time avoiding the necessity of keeping them locked up for the rest of their lives.

Responding to this pressure, several states including California, ${ }^{5}$ Montana, ${ }^{6}$ and Oregon, ${ }^{7}$ have created statutes that require chemical castration, as a prerequisite of release, in certain cases. The underlying concept is that by eliminating the sex drives of these offenders, they will be unable or unwilling to commit another crime; thereby, increasing the likelihood of their becoming

1. Ctr. For SeX OfFender Mgmt., Recidivism For SeX OfFenders 11 (May 2001), available at $\mathrm{http} / / / \mathrm{www} . c s o m . o r g / p u b s /$ recidsexof.pdf [hereinafter RECIDIVISM FOR SEX OFFENDERS].

2. Monica Davey \& Abby Goodnough, Doubts Rise as States Hold Sex Offenders After Prison: Costly Efforts Keep Ex-Convicts Off Streets, but Mandated Treatment Often Fails, N.Y. Tmes, Mar 4, 2007, at A1 [hereinafter Doubts Rise as States Hold Sex Offenders].

3. Id.

4. Id. at $\mathrm{A} 18$.

5. Cal. Penal Code $\S 645$ (1998).

6. Mont. Code ANN. § 45-5-512 (1998).

7. OR. REV. STAT. 144.625 (1998). 
productive members of society. The concept of chemical castration, however, runs afoul of several Constitutional provisions and creates a multitude of legal issues.

This Note will address the problems inherent in the chemical castration model. Part II of this Note will discuss the history of castration and the forms that have evolved over the years in world-wide systems of justice. Part III will examine the latest method of chemical castration, a drug called Depo-Provera, and its effects on the body. Part IV will address overarching constitutional problems. Finally, Part V will discuss the flaws inherent in state statutes that currently provide chemical castration as a parole tool, and briefly analyze how Europeans have approached the castration of sex offenders. All of these Parts will demonstrate why chemical castration is not an effective parole tool.

\section{THE EVOLUTION AND HISTORY OF CASTRATION}

The idea of castration as a punishment did not originate in the United States. It was, in fact, around for centuries before America was even colonized. For example, in ancient times conquering armies would often castrate their captives as punishment for daring to be their enemies. ${ }^{8}$ One of the first uses of castration in the United States occurred during the 1800's, "when slaves were routinely castrated as a punishment if suspected of having relations with white women." However, the official castration of prisoners as a punishment in the United States truly began around $1899 .^{10}$ It was also around this time that the concept of Eugenics first took root in the United States. ${ }^{11}$ The eugenics movement is devoted to improving the human species through the control of hereditary factors in mating. ${ }^{12}$ The essential goal of this movement is to control the gene pool from which children are created by making sure that supposedly "weaker" people do not procreate. ${ }^{13}$ Eugenics led to a movement in which women and men who were convicted of crimes were sterilized to prevent their weaker genes from entering into the human gene pool. ${ }^{14}$ During the early 1900 's, over 60,000 incarcerated or mentally handicapped women were sterilized, in accordance with state statutes, and in the name of the Eugenics movement. $^{15}$

8. William L. Baker, Comment, Castration of the Male Sex Offender: A Legally Impermissible Alternative, 30 LoY. L. REv. 377, 379 (1984).

9. Kris W. Druhm, Note, A Welcome Return to Draconia: California Penal Law $\S 645$, The Castration of Sex Offenders and the Constitution, 61 ALB. L. REV. 285, 286-87 (1997).

10. Louis Le Maire, Danish Experiences Regarding the Castration of Sexual Offenders, 47 J. CRIM. L. CRIMINOLOGY \& POLICE SCI. 294, 294 (1956).

11. Id.

12. WEBSTER'S NEW WORLD Dictionary 468 (3rd ed. 1970).

13. David Morgan, Yale Study: US Eugenics Paralleled Nazi Germany, REUTERS (Feb. 15, 2000), available at http://www.hartford-hwp.com/archives/45/302.html (last visited Mar. 15, 2008).

14. Id.

15. Druhm, supra note 9, at 287. 
Soon, prisoners and their families began challenging the existing statutes, arguing against the constitutionality of these sterilization procedures. Eventually, this issue went before the United States Supreme Court in the case of Buck v. Bell. ${ }^{16}$ In that case, a feeble-minded eighteen year-old woman whose mother was also supposedly feeble-minded was convicted of a crime and then sterilized pursuant to a Virginia law. ${ }^{17}$ The Supreme Court ruled that the statute was constitutional stating, "It is better for all the world, if instead of waiting to execute degenerate offspring for crime, or to let them starve for the imbecility, society can prevent those who are manifestly unfit from continuing their kind." ${ }^{18}$ This opinion has never been overturned, though it has been limited over the years, ${ }^{19}$ and in fact almost every state continues the practice of sterilizing the mentally retarded in certain circumstances. ${ }^{20}$

Ironically, the eugenics movement caught the interest of an aspiring Austrian politician who is today held in ill-repute: Adolf Hitler. Indeed, Hitler based his original political movement, the movement that led to the Holocaust, on the eugenics movement then present in the United States. ${ }^{21}$ He freely admitted his inspiration came from the United States, and was once quoted as saying:

Now that we know the laws of heredity ... it is possible
to a large extent to prevent unhealthy and severely han-
dicapped beings from coming into the world. I have stu-
died with interest the laws of several American states
concerning prevention of reproduction by people whose
progeny would, in all probability, be of no value or be
injurious to the racial stock.

Hitler used the American system as both model and justification for the millions of deaths he caused, and he was actually praised in the beginning by vocal members of the American Eugenics movement. ${ }^{23}$ Joseph Dejarnette, at one time the superintendant of Virginia's Western State Hospital, actually once complained that, "[t]he Germans are beating us at our own game." 24 Given this history, is it any wonder that Americans find statutorily mandated castration so

16. Buck v. Bell, 274 U.S. 200, 200 (1927).

17. Id. at 205.

18. Id. at 207.

19. Robert D. Miller, Forced Administration of Sex-Drive Reducing Medications to Sex Offenders: Treatment or Punishment?, 4 PsYCHOL. PUB. POL'Y \& L. 175, 182 (1998).

20. Gerard S. Leterrie \& William F. Fox, Legal Aspects of Involuntary Sterilization, 53 FERTILITY \& STERILITY 391, 391 (1990).

21. Edwin Black, Hitler's Debt to America, THE GUARDIAN, Feb. 2004, available at http://www.waragainsttheweak.com/offSiteArchive/HitlerDebtToAmerica.html (last visited Mar. 15, 2008).

22. Id.

23. Id.

24. Id. 
disconcerting? As Dr. Fred Berlin once said, "even the mention of castration has an ugly, jarring sound to it."25

\section{DePo-PRovera: THE LATEST METHOd OF ChEMICAL CASTRATION}

The current method of chemical castration used in almost every state that approves of the procedure relies on the drug antiadrogen synthetic progesterone, known also as Depo-Provera, Depot Medroxyprogesterone Acetate, and MPA. ${ }^{26}$ This drug "was first synthesized in 1954 [by the Upjohn Company] and was initially introduced in 1959 as a treatment for gynecological disorders."27 Depo-Provera was first used as an effective way to reduce men's sex drive in $1958 .^{28}$ However, questions arose as to potential long term effects of Depo-Provera, and in 1974 the Food and Drug Administration ("FDA") withdrew their approval for all uses of Depo-Provera. ${ }^{29}$ This ban lasted nearly twenty years, but on October 29, 1992 the FDA again approved Depo-Provera for use in the United States. ${ }^{30}$ At that time, however, the FDA specifically limited the use of Depo-Provera to "the prevention of pregnancy". 31

\section{A. How Depo-Provera Works}

In the context of castration, Depo-Provera is administered as a weekly intramuscular injection in either the arm or the buttocks in a dose of approximately 500 milligrams. ${ }^{32}$ Depo-Provera lowers testosterone levels by (1) increasing testosterone metabolism by the liver and (2) decreasing the amount of luteinizing hormone ("LH") and follicle-stimulating hormone ("FSH") released. $^{33}$ To aid this hormone decrease, Depo-Provera inhibits the release of LH and FSH from the anterior pituitary gland of the brain. ${ }^{34}$ It also "works by induction of the enzyme testosterone-A-ring-reductase in the liver, accelerating the breakdown and elimination of testosterone." 35 Depo-Provera lowers testosterone levels, causing the subject to experience a decrease in sex drive, a reduc-

25. Stacy Russell, Comment, Castration of Repeat Sexual Offenders: An International Comparative Analysis, 19 Hous. J. INT'L. L. 425, 440 (1997).

26. William Green, Note, Depo-Provera, Castration, and the Probation of Rape Offenders: Statutory and Constitutional Issues, 12 U. DAYTON L. REV. 1, 3 (1986).

27. Philip J. Henderson, Note, Section 645 of the California Penal Code: California's "Chemical Castration" Law - A Panacea or Cruel and Unusual Punishment?, 32 U.S.F. L. REV. 653, 654 (1998).

28. $I d$.

29. Warren E. Leary, U.S. Approves Injectable Drug as Birth Control, N.Y. TIMES, Oct. 30, 1992, at A1.

30. Henderson, supra note 27 , at 655 .

31. PHYSICIAN's DESK REFERENCE 2080 (51 st ed. 1997) [hereinafter PDR].

32. Marsha Weissman \& Richard Luciani, Sentencing the Sex Offender: $A$ Defense Perspective, Crim. L. \& URB. ProBs. 259, 270 (1989).

33. Miller, supra note 19 , at 182.

34. Id.

35. Id. 
tion in sperm product, fewer erections, and a reduction in ejaculations while he is under the effects of the drug. ${ }^{36}$ As the dosage level increases, so does the reduction of testosterone and the ability to sustain erections. ${ }^{37}$

\section{B. The Side-Effects of Depo-Provera}

In studies of Depo-Provera, both those studies done for FDA approval and other later studies, an array of side effects were reported. In the short-term, subjects reported weight gain, hyperinsulinemic response to glucose, diabetes mellitus, irregular gall bladder functioning, diverticulitis, fatigue or lethargy, testicular atrophy, sweats, nightmares, dyspnea, hypogonadism, hot and cold flashes, leg cramps, hypertension, thrombosis, insomnia, elevated blood sugar, shortness of breath, and lessened testis size. ${ }^{38}$ All listed side effects were shown to disappear when Depo-Provera was disused; however, it could take up to six months for full sexual functioning to return. ${ }^{39}$ It is important to note that the studies on side effects and the duration of the side effects were all based upon Depo-Provera's use as a female contraceptive. ${ }^{40}$ The amount of DepoProvera "used to reduce testosterone in men is, on the average, over forty-three times more than what is given to woman as a contraceptive." Considering this fact, it is unclear whether the side effects that may be temporary in women could ultimately be more severe and/or permanent in male sex offenders.

Beyond the short-term side effects, there is evidence that Depo-Provera may have long-term effects. Depo-Provera "may be considered among the risk factors for development of osteoporosis." Also, long term usage by sex offenders can cause massive weight gain and the formation of breasts. ${ }^{43}$ In addition, some studies believe that Depo-Provera may be a carcinogen in animals; there is some evidence that Depo-Provera causes breast cancer in both beagles and monkeys. ${ }^{44}$ But there is no evidence currently in existence and known to the general community that shows humans are at risk for cancer from DepoProvera. In fact, the FDA found that "although early animal studies had raised questions about increased breast-cancer risk, numerous later worldwide studies have found the overall cancer risk in humans to be minimal, if any. "45 Most of

36. Pamela K. Hicks, Commentary, Castration of Sexual Offenders, 14 J. LEGAL MED. 641, 646 (1993).

37. John Money, Treatment Guidelines: Antiandrogen and Counseling of Paraphilic Sex Offender, 13 J. SEX. \& MARITAL THERAPY 219, 220 (1987).

38. Miller, supra note 19, at 182.

39. Id.

40. Henderson, supra note 27, at 656.

41. Id.

42. PDR, supra note 31 , at 2080.

43. Monica Davey \& Abby Goodnough, For Sex Offenders, Dispute on Therapy Benefits, N.Y. TIMES, Mar. 6, 2007, at A18 [hereinafter Dispute on Therapy Benefits].

44. Edward A. Fitzgerald, Note, Chemical Castration: MPA Treatment of the Sex Offender, 18 AM. J. CRIM. L. 1, 8 (1990).

45. Leary, supra note 29 , at A1. 
these studies, however, focused on women and the effects of Depo-Provera on them. Very little is known about possible health threats posed when the dosage of Depo-Provera is increased to the levels used to suppress the sex drives in male sex offenders simply because usages for that purpose have not been studied. This makes it difficult to assess what, if any, long term effects constant high dose Depo-Provera usage would have on the human body, or how long the changes caused by Depo-Provera injections would last once the injections were stopped.

\section{Depo-Provera's Limitations: How They Affect Any Potential Statutory Implementations}

Beyond the long list of potential side effects, Depo-Provera, as a cure all for sex offenders, is further limited by the types of sex offenders for which it may provide a useful benefit.

Sex offenders can be divided into four types. Type I denies the commission of the crime or the criminal nature of the act. Type II confesses to the commission of the crime, but places the blame for the crime on nonsexual or non-personal forces, such as alcohol, drugs, or stress. Type III is the violent criminal who is motivated by nonsexual gain, such as anger, power, or violence. Type IV is the paraphiliac who exhibits a pattern of sexual arousal, erection, and ejaculation, which is characterized by a specific fantasy or its actualization. ${ }^{46}$

Depo-Provera can only truly be effective if the reasons behind the sexually based crime stem from sexual desire or have some sexually based rationale. After all, if sex drive was the cause, Depo-Provera's ability to reduce a person's sex drive could in theory be effective. Type I, II, and III sex offenders do not, however, have a sexual motivation. ${ }^{47}$ Rather, a nonsexual motive drives these individuals to commit a sexual offense. ${ }^{48}$ It is poor policy to release a sex offender whose motivation is not sexual desire and then hope Depo-Provera will reduce sexual ability and thus lower recidivism. Perhaps that is why a recent study that followed the release of certain sex offenders found that while only twenty-eight percent were reconvicted for sexual offenses, forty-three percent were reconvicted for a violent, nonsexual offense. ${ }^{49}$

In addition to Depo-Provera only having a real chance of working for Type IV sex offenders, Depo-Provera alone is not truly effective. To have a

46. Fitzgerald, supra note 44 , at 4.

47. Id.

48. Id.

49. RECIDIVISM FOR SEX OFFENDERS, supra note 1 , at 8. 
realistic chance of being effective, Depo-Provera needs to be linked and used in tandem with psychological treatment on those that have a potential for being helped by the drug. ${ }^{50}$ A recent study found that a significantly higher percentage of sex offenders given treatment along with drug options experience a lower recidivism rate than those given just the drug. ${ }^{51}$ Therefore, any statutory requirement of chemical castration, as a parole condition, must not only be very limited in its use and create a great deal of discretion in its application, it must also require, or at least encourage, some form of therapy to go in tandem with Depo-Provera.

\section{CHEMICAL CASTRATION: THE CONSTITUTIONAL IMPLICATIONS}

Chemical castration as a general concept raises several important constitutional issues that must be considered and addressed before any statute or law can be created that is constitutional on its face.

\section{A. Eighth Amendment Problems}

Perhaps the greatest constitutional hurdle facing the usage of chemical castration on sex offenders is the Eighth Amendment. This Amendment states "[e]xcessive bail shall not be required, nor excessive fines imposed, nor cruel and unusual punishments inflicted." 52 Several legal issues arise when applying this amendment to the concept of chemical castration.

\section{Is Chemical Castration Treatment or Punishment?}

In order for chemical castration to be considered under an Eighth Amendment analysis, it must first be determined whether chemical castration is a punishment. If it is a punishment, it falls under the purview of the Eighth Amendment. Conversely, if it is treatment, it lies outside the scope of the Eighth Amendment. Given its long list of side effects and the adverse effect it has on the male sex drive, Depo-Provera could easily be seen as a punishment by people outside of the legal or psychiatric communities. However, just because Depo-Provera can be seen as a punishment by some, that fact does not automatically make the statutorily mandated use of Depo-Provera a punishment suitable for an Eighth Amendment analysis. After all, "the emotional reaction engendered by criminal sexual behavior makes it unlikely that society will accept treatment as a sentencing option unless it is clearly viewed as punish-

50. John B. Murray, Psychopharmacological Therapy of Deviant Sexual Behavior, $115 \mathrm{~J}$. GEN. PSYCHOL. 101, 107 (1988).

51. RECIDIVISM FOR SEX OFFENDERS, supra note 1 , at 13 (finding a $7.2 \%$ recidivism rate for sex offenders who participated in relapse prevention treatment programs used in conjunction with Depo-Provera compared to a $17.6 \%$ rate when only Depo-Provera was used).

52. U.S. CONST. amend. XVIII. 
ment." 53 Therefore, the only real way to provide treatment to sex offenders is to cloak the treatment in the aura of punishment to get it past people outside the legal community. While the legal community's view is important, however, other views must also be considered when determining Depo-Provera's status. Specifically, the psychiatric community's view of Depo-Provera is important in making this critical determination.

Within the psychiatric community, treatment with Depo-Provera is viewed as a viable way to reduce sex drives. However, some members of the community are disturbed by the concept of statutorily mandated Depo-Provera usage by parolees. Dr. Robert D. Miller wrote on this subject:

It is important to recognize that the only clinically appropriate use of all these medications with sex offenders is to reduce abnormally excessive sexual drives or fantasies, not to render the patient impotent. Therefore, the very phrase chemical castration implies a medically inappropriate use of the medications. To use such medications to reduce future illegal sexual behavior, especially in an involuntary fashion, is not treatment any more than is incarceration. ${ }^{54}$

This is an indication that there is some disagreement and unrest among the psychiatric and medical communities on whether Depo-Provera is a treatment or a punishment.

Though the opinion of the medical community and that of the average person could be an influence on the question of treatment or punishment, the real underlying question is whether or not chemical castration meets the legal standard to qualify as treatment. First, it is almost irrelevant whether a statute specifically states that a specific course of action is for treatment or for punishment. The Supreme Court has held that the mere characterization of an act as "treatment" does not insulate it from Eighth Amendment scrutiny. ${ }^{55}$ Instead, an inquiry must be made directed towards the substance, since "[e]ven a clear legislative classification of a statute as 'non-penal' would not alter the fundamental nature of a plainly penal statute." statute or concept, however, it is important to understand what standard it will be compared to in order to decide if it violates the Eighth Amendment.

53. Berlin and Malin, Media Distortion of the Public's Perception of Recidivism and Psychiatric Rehabilitation, 148 AM. J. PsYCHIATRY 1572, 1572 (1991); see also Daniel L. Icenogle, Sentencing Male Sex Offenders to the Use of Biological Treatments: A Constitutional Analysis, 15 J. LEGAL MED. 279, 280 (1994).

54. Miller, supra note 19 , at 183.

55. Trop v. Dulles, 356 U.S. 86, 95 (1958).

56. Id. 
The applicable standard in this situation was first articulated in the case of Rennie $v$. Klein. ${ }^{57}$ In that case, an involuntary mental patient in New Jersey argued that he had the right to refuse medication since this was a nonemergency situation and that to force medication on him would qualify as cruel and unusual punishment under the Eighth Amendment. ${ }^{58}$ The court in Rennie reviewed both the evidence at hand and the factors considered by previous Supreme Court cases when determining the crucial question of treatment or punishment. The court then outlined the following four prongs that must be shown to make a determination on whether a medical action qualifies as treatment: (1) whether the procedure has any therapeutic value; (2) whether the procedure is part of an accepted medical practice or is experimental in nature; (3) whether the adverse effects of the procedure seem unduly harsh; and (4) whether the procedure is "part of an ongoing psychotherapeutic program." 59

Under the first prong of the test, chemical castration may qualify. There is some evidence that Depo-Provera, used in conjunction with therapy and other psychological techniques, may be beneficial to a patient. ${ }^{60}$ A recent study of the recidivism rates among sex offenders did show a decrease when DepoProvera was used. ${ }^{61}$ However, it is difficult to be certain of those rates, as there are some problems that seem inherent when collecting data in the area of sexual offenses. First, very few of the overall total sexual offenses are reported. ${ }^{62}$ For example, a recent study found that only twelve percent of actual rapes are reported. ${ }^{63}$ Another study found that actual numbers of sexual offenses could be as much as 2.5 times as high as reported. ${ }^{64}$ Since these types of offenses are so under-reported, it is probable that some repeat offenders using Depo-Provera exist, but these repeat offenses are not reported.

The second prong of the test is whether the potential treatment is an accepted medical practice, and under this prong chemical castration will likely succeed. Though the specific usage of Depo-Provera as a condition of parole or as an additional punishment may not be generally accepted in the psychiatric community, the use of Depo-Provera is a generally accepted medical practice. The medical community considers it an effective way to reduce abnormally excessive sexual drives or fantasies, ${ }^{65}$ and to provide a way to treat people suffering from some mental illnesses when used in conjunction with treatment. ${ }^{66}$ One psychiatrist said, “[c]onsequently, since the source of pedophile's behavior is

57. Rennie v. Klein, 462 F.Supp 1131, 1131 (D.N.J. 1978).

58. Id. at 1143 .

59. Id.

60. RECIDIVISM FOR SEX OFFENDERS, supra note 1, at 11.

61. Id.

62. CTR. For SeX OfFender Mgmt., Myths ANd Facts About Sex OfFenders (Aug. 2000), http://www.csom.org/pubs/mythsfacts.html (last visited Mar. 15, 2008).

63. Id.

64. RECIDIVISM FOR SEX OFFENDERS, supra note 1, at 11.

65. Miller, supra note 19, at 183.

66. Money, supra note 37, at 220. 
biological, Depo-Provera is very effective because it suppresses their unacceptable sexual urges by decreasing the testosterone levels that drive them. ${ }^{, 67}$ Since there are some accepted instances when Depo-Provera is effective, it would likely be considered an accepted medical practice generally. However, the current application of Depo-Provera as a parole condition would likely not be considered an effective medical use for the drug. In this context, Dr. Robert Miller stated:

It is important to recognize ... that the only clinically appropriate use of all these medications with sex offenders is to reduce abnormally excessive sexual drives or fantasies, not to render the patient impotent. Therefore, the very phrase chemical castration implies a medically inappropriate use of the medications. To use such medications to reduce future illegal sexual behavior, especially in an involuntary fashion, is not treatment any more than is incarceration. ${ }^{68}$

The third prong of the test is whether the supposed treatment is unduly harsh, and chemical castration likely fails to qualify as treatment under this prong. Depo-Provera has a very long list of potential side effects, and some of them, such as diabetes mellitus and irregular gallbladder functioning, are quite serious. ${ }^{69}$ While it can be argued that these side effects only persist as long as Depo-Provera is used, parolees and prisoners are still forced to live with these harsh side effects in order to take a drug that may or may not prevent them from committing another sexual crime. Also, while there has been no hard evidence of Depo-Provera causing adverse long-term side effects in humans, studies have shown that Depo-Provera caused breast cancer in beagles, ${ }^{70}$ and may cause osteoporosis in humans. ${ }^{71}$ Therefore, it may be unduly harsh to make patients risk potential long-term effects while battling all the short-term side effects to take a drug that may or may not prevent them from committing another sexual offense.

The final prong of the test is whether the process is part of an ongoing psychotherapeutic program. It is likely that chemical castration will fail to be considered treatment under this prong. In theory, chemical castration can be used in conjunction with psychotherapy or psychosurgery as an effective treatment process for some mental illnesses. ${ }^{72}$ A problem occurs, however, when an

67. Fred S. Berlin, The Paraphilias and Depo-Provera: Some Medical, Ethical, and Legal Considerations, 17 BULl. AM. ACAD. PsYCHIATRY L. 233, 235-36 (1989).

68. Miller, supra note 19 , at 183.

69. Id. at 182.

70. Fitzgerald, supra note 44 , at 8 .

71. PDR, supra note 31 , at 2080.

72. Money, supra note 37, at 13. 
attempt is made to transform theory into a practical treatment regime. So far, as discussed below, no state that allows chemical castration has created a system that effectively links the use of Depo-Provera with psychotherapy; thereby, ensuring that people who take the drug will actually take it as part of an ongoing psychotherapeutic process. For this reason, chemical castration will likely fail the fourth prong of the test.

\section{Is Chemical Castration Cruel and Unusual Punishment?}

Assuming that chemical castration would not be considered treatment, the next question is whether it would actually be cruel and unusual to require sex offenders to take Depo-Provera as a condition of their parole. In order to determine this, the legal standard for what constitutes cruel and unusual punishment must be explored. One potential legal test to determine what is cruel and unusual was outlined by the United States Supreme Court in the case of Furman v. Georgia. ${ }^{73}$ In that case, the court outlined the potential test as follows:

The test, then, will ordinarily be a cumulative one: If a punishment is unusually severe, if there is a strong probability that it is inflicted arbitrarily, if it is substantially rejected by contemporary society, and if there is no reason to believe that it serves any penal purpose more effectively than some less severe punishment, then the continued infliction of that punishment violates the command of the Clause that the State may not inflict inhuman and uncivilized punishments upon those convicted of crimes. ${ }^{74}$

Therefore, it must be determined where chemical castration falls under each of three prongs: (1) whether the punishment is inherently cruel; (2) whether the punishment is proportional to the crime; and (3) whether the punishment is excessive in relation to the achievement of legitimate state goals.

Under the first prong, chemical castration will probably qualify as inherently cruel. Essentially, inherently cruel punishments are those that are "inflicted in wholly arbitrary fashion" or "clearly and totally rejected throughout society." ${ }^{\text {"75 }}$ Therefore, the question is whether stopping a man from being able to have any real sex drive and inflicting an array of side effects is clearly and totally rejected throughout society. It can be argued that the use of chemical castration on sex offenders does meet the standard of being clearly and totally

73. Furman v. Georgia, 408 U.S. 238, 238 (U.S. 1972).

74. Id. at 282 (Brennan, J., concurring) (This opinion was one of a series of concurring opinions in which no more than two judges agreed on this issue. Future cases have used this standard and have not been overturned.).

75. Id at 281 . 
rejected. As Dr. Fred Berlin stated, "Even the mention of castration has an ugly, jarring sound to it." forced on a normal person, then why should someone convicted of a sexual offense be treated as less than an average person? However, given the prevalence of chemical castration programs and statutes, the use of Depo-Provera injections on sex offenders is not likely to meet this standard.

The next prong is whether chemical castration is proportional to the crime, and the answer is no. When asking whether a punishment is proportional to the crime, it is wise to examine factors such as: how the punishment comports with society's view of decency, whether the punishment is proportional to other serious crimes, and whether the punishment is consistent with that afforded to similar crimes in other jurisdictions. ${ }^{77}$ First, the concept of chemical castration does not likely comport with society's view of decency, as it involves forcing people to take drugs with many side effects. It is essentially giving the state control of one's body, which is not considered decent by most of society.

Second, this punishment is not proportional compared to other serious crimes. Most people consider sexual offenses among the worst crimes a person can commit. It is logical to compare the punishment of sexual offenses to the punishment of other horrible crimes such as murder. With murder, drugs are not usually forced on someone unless they are to be given a lethal injection under the death penalty. Instead, more time is spent in prison as a way of keeping the person away from society. This does not comport with the goal of chemical castration: get sexual offenders onto the street quicker while at the same time preventing recidivism. While it is true that states have been civilly committing sex offenders to keep them off the streets longer, ${ }^{78}$ that is counter to the purpose of chemical castration. In fact, the only time drugs are administered as a form of punishment is when a person is judged not guilty by reason of mental defect and then given medication as part of their required treatment in a state mental institution.

Comparing that situation to chemical castration does provide several similarities. For example, the motive and justification behind both options are fairly similar. The common rationale behind civil commitment and chemical castration is the protection of the public in a way that prevents sex offenders from being a danger to society. In that context, treatment, as motive, remains a distant concern. Moreover, criminals found not guilty by reason of mental disease or defect, are not per se being punished. Instead, because they are unable to comprehend that what they did was wrong such criminals are committed and given treatment in an attempt to help them. Conversely, sex offenders are being punished through prison terms and then chemically castrated in an attempt to maintain control over them once they are released. Therefore, given the dis-

76. Russell, supra note 25 , at 440 .

77. Fitzgerald, supra note 44, at 38.

78. Doubts Rise as States Hold Sex Offenders, supra note 2, at A18. 
parity of purpose and reasoning between those criminals found guilty by reason of mental disease or defect and those sex offenders who are forced to undergo chemical castration, a comparison actually is inappropriate.

Next, the question of whether the punishment is consistent to that afforded to similar crimes in other jurisdictions needs to be answered. There are several problems with trying to make a comparison among the various state jurisdictions that allow chemical castration. First, the way states handle chemical castration varies greatly. Some states civilly commit sex offenders they consider dangerous as soon as they are released from prison, and the federal government supports these civil commitments. ${ }^{79}$ In fact, President Bush recently signed a law offering money to states that commit sex offenders beyond the terms in prison they were assigned by the justice system, and the Justice Department is actually creating a program for federal prisoners that will civilly commit some sex offenders. ${ }^{80}$ Other states take no additional action against sex offenders. Trying to compare these different methods to states that use chemical castration is not a way to determine similarity. It would be like comparing apples and oranges.

Even if a comparison is made solely among those states that choose chemical castration as a way to handle their sex offenders, problems still exist. There is no standard methodology or protocol. As discussed later in this Note, the various states that do use chemical castration have different requirements, standards, and punishment lengths. Essentially, how Depo-Provera is applied and how states determine that the application of chemical castration is warranted is very inconsistent. In some cases, the decision to utilize chemical castration may be very arbitrary and dependent on judges to decide which sex offenders get drugs forced on them and which ones do not. This disparity in methods, protocols, and reasoning makes it difficult to have a baseline test for whether the application of chemical castration in one state is disproportionate when compared to the application in other jurisdictions.

The final prong to examine in answering the question of whether chemical castration is cruel and unusual is whether the punishment is excessive when compared to the state's legitimate interest. Chemical castration may actually pass this prong. The state has a legitimate interest in exercising its police power to protect the public safety. ${ }^{81}$ One of the fundamental cornerstones of this power is the protection of children. ${ }^{82}$ Since certain types of sex offender choose children as their target, ${ }^{83}$ the state's interest is increased. Given the strong state interest that is present in such instances, chemical castration will probably pass this prong. Ultimately, however, chemical castration will likely fail an Eighth

79. Id.

80. Id.

81. Nollan v. Cal. Coastal Comm'n, 483 U.S. 825, 837 (1987).

82. Sable Commc'n v. F.C.C., 492 U.S. 115, 115 (1989).

83. Fitzgerald, supra note 44, at 4 (In this instance, the type of sex offenders mentioned is referring to Type IV Sex Offenders, or more specifically pedophiles.) 
Amendment challenge because it is unlikely to pass the first or second prongs of the test.

\section{The Issue of Consent}

Another issue that comes up under the Eighth Amendment is consent. Assuming chemical castration is considered treatment, the sex offender must still consent to such treatment before it can be administered, or else it would violate the Eighth Amendment. ${ }^{84}$ In order to have informed consent as required under the Eighth Amendment, two elements must be satisfied: information and voluntariness. $^{85}$

The first element is that of information, which is not met when dealing with chemical castration. In order for this element to be met, all the relevant information must be given to someone before they can consent. Whether information is relevant is based on the following four prongs: the risks, the anticipated benefits, the consequences without treatment, and the alternatives. ${ }^{86}$ In general, it is better to err on the side of caution and tell the sex offender all medically relevant facts and potential consequences from using Depo-Provera. In theory, if the sex offender was told all potential short-term and long-term side effects then this element would be fulfilled and consent could be legally given. In practice, however, none of the state statutes discussed later contain any requirement that a sex offender be informed of the risks and side effects of Depo-Provera ${ }^{87}$ In addition, "because all of the long-term side effects of DepoProvera treatment are not yet known, there cannot be any true informed consent." ${ }^{\circ 8}$

The other element that must be met for informed consent to be given is that consent must be voluntary. Chemical castration with Depo-Provera, as currently utilized, may not satisfy this element. Most statutes require DepoProvera as a condition of parole, which implies that a sex offender may either take Depo-Provera risking permanent physical alteration or go back to prison. ${ }^{89}$ When faced with only these choices, is voluntary consent really possible? The Supreme Court has not made a final ruling on this issue, and different states have come to different conclusions. For example, in Maryland the courts have held that prisoners can give adequate consent for experimental or non-medical procedures even if they are in prison. ${ }^{90}$

84. Bailey v. Lally, 481 F.Supp. 203, 219 (D.C.Md. 1979).

85. Id. At 220.

86. Canterbury v. Spencer, 464 F.2d 772, 787-89 (D.C. Cir. 1972).

87. See generally Part V of this Note.

88. Druhm, supra note 9, at 306.

89. See generally Part V of this Note.

90. Bailey, 481 F. Supp. at 220-21. 


\section{B. The Equal Protection Claim}

Chemical castration may qualify for an equal protection claim, at which point several problems arise. An equal protection argument is made based on the Fourteenth Amendment, which states:

All persons born or naturalized in the United States, and subject to the jurisdiction thereof, are citizens of the United States and of the state wherein they reside. No state shall make or enforce any law which shall abridge the privileges or immunities of citizens of the United States; nor shall any state deprive any person of life, liberty, or property, without due process of law; nor deny to any person within its jurisdiction the equal protection of the laws. ${ }^{91}$

Before an equal protection claim can be made, however, it must first be determined which of the standards of review used in equal protection claims apply. The three standards are: (1) strict scrutiny which requires a compelling governmental interest and for the statute to be narrowly tailored,,$^{92}(2)$ intermediate scrutiny which requires an important governmental interest that is substantially related to the statute, ${ }^{93}$ and (3) rational basis review which requires a legitimate governmental interest and that there be a reasonably conceivable set of facts that makes the statute rationally related to that interest. ${ }^{94}$

\section{The Strict Scrutiny Standard and Its Requirements}

Chemical castration statutes would not likely satisfy the standard of review for strict scrutiny. The standard of review for strict scrutiny requires a compelling state interest and a narrowly tailored statute. ${ }^{95}$ First, chemical castration does likely satisfy a compelling state interest. The state has a compelling interest in the use of its police power to protect its citizens, and given the high recidivism rates among sex offenders, ${ }^{96}$ an argument can be made that a compelling state interest is present when chemical castration is employed. Most if not all chemical castration statutes will, however, fail to meet the narrow tailoring provision of the strict scrutiny standard. To be narrowly tailored the statute must be neither over nor under-inclusive. With regard to chemical castration statutes, there usually exists a problem of over-inclusion. As dis-

91. U.S. Const. amend. XIV $\S 1$.

92. Grutter v. Bollinger, 539 U.S. 306, 308 (2003).

93. Taun Anh Nguyen v. I.N.S., 533 U.S. 53, 70(1976).

94. F.C.C. v. Beach Commc'n, Inc., 508 U.S. 307, 314-16 (1993).

95. Grutter, 539 U.S. at 308.

96. RECIDIVISM FOR SEX OFFENDERS, supra note 1 , at 11. 
cussed in Part V of this Note, most of the statutes do not differentiate between the various sex offender types and classifications. The statutes allow judges to assign chemical castration as a condition of parole to any sex offender, even though only certain types of sex offenders would benefit from Depo-Provera injections. ${ }^{97}$ Therefore, most chemical castration statutes in effect force some sex offenders to take Depo-Provera injections that would neither help them nor make them less likely to commit another sexual offense. For this reason, the chemical castration statutes are usually over-inclusive and would fail an equal protection claim under the strict scrutiny standard.

Though chemical castration would probably fail under a strict scrutiny standard, there is very little chance it would be argued under such a standard. To qualify for a strict scrutiny standard, there must be either disparate treatment

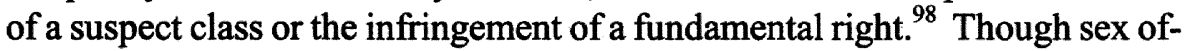
fenders have been discriminated against and targeted by law enforcement and state governments, they do not qualify as a suspect class. There is also probably not a fundamental right being infringed upon, so strict scrutiny would not be the correct standard to apply in regards to chemical castration of sex offenders.

\section{The Intermediate Scrutiny Argument in Regards to Chemical Castration}

The standard to be used when examining a statute under intermediate scrutiny is whether there is an important governmental interest involved, and protecting that interest is substantially related to the statute. ${ }^{99}$ Chemical castration probably passes under the first element, which requires an important governmental interest to be at stake. The state does have an important interest in protecting its citizens by exercising its police power, and it can be argued that requiring some sex offenders to take injections of Depo-Provera, to reduce the chance that they will re-offend, falls under that interest.

The second element of the intermediate scrutiny standard is that the interest be substantially related to the statute, and chemical castration meets this element. ${ }^{100}$ The states that have created chemical castration statutes have all done so with the stated purpose of trying to ensure that sex offenders do not commit another sex offense; thereby, winding up back in prison. Clearly, any reduction in sex offender recidivism would be substantially related to a state's interest in the protection of its citizens. However, the use of chemical castration in many of the states is rather indiscriminate, and Depo-Provera is forcibly given to people for whom the drug will not be helpful. The general rule is that "MPA should only be prescribed for those offenders to whom it offers the

97. Only Type IV sex offenders would find Depo-Provera injections helpful in preventing future crimes and treating their problem. See Fitzgerald, supra note 44, at 4.

98. Johnson v. California, 543 U.S. 499, 505 (1945).

99. Taun Anh Nguyen, 533 U.S. at 70.

100. Id. 
promise of hope. Otherwise, MPA is an inappropriate or ineffective treatment. ..." ${ }^{\prime 101}$ Therefore, most state statutes that deal with the chemical castration of sex offenders would probably survive an equal protection challenge under intermediate scrutiny.

There may, however, be one valid argument that chemical castration statutes fall under intermediate scrutiny. Indeed, one classification that warrants intermediate scrutiny are statutes that discriminate based on gender. In the case of using Depo-Provera injections on sex offenders, there is a strong argument that the use of Depo-Provera in this manner discriminates based on gender. Depo-Provera is given to sex offenders so that their sex drives will be reduced. The purpose for which Depo-Provera is given to sex offenders, the reduction of their sex drives, is usually effective only when the drug is given to males. ${ }^{102}$ When Depo-Provera is given to females, it is usually prescribed for birth control. ${ }^{103}$ The effect of Depo-Provera on the female sex drive has not been studied and is currently unknown. There is evidence, however, that Depo-Provera does reduce the ability of men to sustain erections and does reduce their sexual drive. ${ }^{104}$ Therefore, when Depo-Provera is administered to sex offenders, it is being administered primarily, if not entirely to men. Thus, the chemical castration statutes discriminate along gender lines. Gender discrimination, however, does not automatically imply that chemical castration will fail an equal protection challenge. The Supreme Court has held that "the Equal Protection Clause does not mean that the physiological differences between men and women must be disregarded. ... The Constitution surely does not require a State to pretend that the demonstrable differences between men and women do not exist." 105 Therefore, most hypothetical and real chemical castration statutes would likely survive an equal protection challenge under the intermediate scrutiny standard of review.

\section{Rational Basis Review: Its Result When Applied to Chemical Castration}

An equal protection challenge to chemical castration statutes would most likely fall under the rational basis standard of review. Chemical castration statutes are discriminatory, in that they separate some male sex offenders, in terms of a possible sentence and punishment, from both other male sex offenders and from non-sex crime offenders. Based on this disparate treatment, an equal protection claim could be brought against chemical castration statutes under a rational basis review.

To survive rational basis review, a statute must advance a legitimate governmental interest and there must be some reasonably conceivable set of facts

101. Fitzgerald, supra note 44 , at 59.

102. Money, supra note 37 , at 220.

103. PDR, supra note 31 , at 2080.

104. Money, supra note 37, at 220.

105. Michael M. v. Super. Ct., 450 U.S. 464, 481 (1981). 
that makes the statute rationally related to that interest. ${ }^{106}$ Chemical castration statutes would almost definitely pass a challenge under this standard. Courts rarely overturn a statute based on rational basis review, as in almost any situation a legitimate governmental interest can be found and some reasonably conceivable facts could be hypothesized that rationally relate the statute to the interest. The state can argue that it has a legitimate interest in protecting its citizens from sex offenders, and administering Depo-Provera injections to reduce the sex drive of sex offenders rather than non-sex offenders is rationally related to that interest. Therefore, it is almost certain that any hypothetical or real chemical castration statute would survive an Equal Protection challenge if rational basis is the standard of review used by the court.

Though most chemical castration statutes would not survive a strict scrutiny standard, it is exceedingly unlikely that the strict scrutiny standard would be applied. Instead, either intermediate scrutiny at best or rational basis review at worst would be the standard a court uses to judge the equal protection claim. Under both of those standards, however, most hypothetical or real chemical castration statutes would pass. Consequently, because chemical castration statutes would likely survive an attack under both the intermediate and rational basis standards of review, an equal protection challenge will probably fail.

\section{The Problem of Double Jeopardy}

Another constitutional issue that arises from the use of Depo-Provera on sex offenders is the concept of double jeopardy. This concept is based on the Fifth Amendment, which states:

No person shall be held to answer for a capital, or otherwise infamous crime, unless on a presentment or indictment of a Grand Jury, except in cases arising in the land or naval forces, or in the militia, when in actual service in time of War or public danger; nor shall any person be subject for the same offence to be twice put in jeopardy of life or limb; nor shall be compelled in any criminal case to be a witness against himself, nor be deprived of life, liberty, or property, without due process of law; nor shall private property be taken for public use, without just compensation. ${ }^{107}$

Essentially, double jeopardy means that a person cannot be tried or punished for the same crime twice. Double jeopardy protections might attach to "a second prosecution for the same offense after acquittal; a second prosecution

106. Beach Commc'n, 508 U.S. at 314-316.

107. U.S. ConsT. amend. V (emphasis added). 
for the same offense after conviction; and multiple punishments for the same offense." 108 The U.S. Supreme Court has held that the concept of double jeopardy applies to both being convicted for the same crime twice and being punished for the same crime twice. ${ }^{109}$ An argument can be made that chemical castration violates double jeopardy. As discussed in Part V of this Note, infra, several states require parolees to take Depo-Provera until the Department of Corrections in that state decides it is no longer necessary. ${ }^{110}$ There is a very real possibility in these states that a sex offender could be required to receive DepoProvera injections beyond their parole. If that possibility materialized, the punishment as implemented would actually extend beyond the term of the original punishment sentenced (time incarcerated and time on parole). It could, therefore, be argued that requiring Depo-Provera treatments, as a condition of parole that extends beyond the time a sex offender is on parole, would result in the court issuing two punishments for the same crime; thereby, violating the Fifth Amendment. This is especially true if the sex offender was tried and convicted of his crime before the state adopted its chemical castration statute. Conversely, if the sex offender was convicted after the state statute was enacted, it could be argued that the original punishment included a chemical castration parole condition and does not, therefore, violate double jeopardy protections.

\section{CURRENT STATE STATUTES AND THEIR INHERENT FLAWS}

\section{A. California's Chemical Castration Statute}

In 1996, California amended its criminal statutes through Assembly Bill 3339 to add chemical castration as a possible punishment or parole requirement for sex offenders. ${ }^{111}$ The bill, which was passed and became a law, states in pertinent part:

(a) Any person guilty of a first conviction of any offense specified in subdivision (c), where the victim has not attained 13 years of age, may, upon parole, undergo medroxyprogestrone acetate treatment or its chemical equivalent, in addition to any other punishment prescribed for that offense or any other provision of law, at the discretion of the court.

(b) Any person guilty of a second conviction of any offense in subdivision (c), where the victim has not at-

108. United States v. Halper, 490 U.S. 435,440 (1989).

109. Abney v. United States, 431 U.S. 651, 660 (1977).

110. See infra Part V. None of the state statutes discussed later establish a definite termination date for the Depo-Provera treatment.

111. Henderson, supra note 27, at 653. 
tained 13 years of age, shall, upon parole, undergo medroxyprogestrone acetate treatment or its chemical equivalent, in addition to any other punishment prescribed for that offense or any other provision of law.... (d) The parolee shall begin medroxyprogesterone acetate treatment one week prior to his or her release from confinement in the state prison or other institution and shall continue treatments until the Department of Corrections demonstrates to the Board of Prison Terms that this treatment is no longer necessary.

(e) If a person voluntarily undergoes a permanent, surgical alternative to hormonal chemical treatment for sex offenders, he or she shall not be subject to this section. $^{112}$

This statute, hailed by many in California as a possible solution for the problems created by sex offenders generally, is plagued by several serious flaws that render it both problematic and constitutionally suspect.

First, the statute does not require any medical expert's input or diagnosis of the sex offender. ${ }^{113}$ Thus, judges must act as a medical doctor ("MD") and determine for themselves whether Depo-Provera would be useful. However, this inquiry applies only to first offenses. According to this statute, second-time offenders against children under the age of thirteen shall automatically receive chemical castration as a condition of parole without any medical considerations. ${ }^{114}$ Also, since there is no requirement that a judge listen to a doctor, the judge can actually overrule a consulting physician since the statute relies heavily on judicial discretion. ${ }^{115}$ This shortcoming was best illustrated in the case of State v. Estes. ${ }^{116}$ Though this case does not come from California, it deals with the same underlying problem of unchecked judicial discretion and arbitration with regard to medical and/or psychiatric determinations.

In Estes, a man kidnapped a young boy and pled to first degree kidnapping. ${ }^{117}$ The doctor who examined the defendant believed the man to be a pedophile and recommended that he be put on Depo-Provera. ${ }^{118}$ However, the judge held that "even though Estes may be treatable with the aid of DepoProvera under the right conditions and circumstances, there is no guarantee of success and in reality, the odds are against it."119 The judge "placed the greatest emphasis on the need to protect society" and proceeded to overrule the opin-

112. Cal. Penal Code $\S 645$ (1998).

113. Id.

114. Id.

115. Id.

116. State v. Estes, 821 P.2d 1008, 1009 (Idaho Ct. App. 1991).

117. Id.

118. Id.

119. Id at 1009-10. 
ion of the medical expert and gave the man a lengthy prison sentence. ${ }^{120}$ In this example, a medical expert was ignored and a judge decided his knowledge of how to handle potential sex offenders was greater than medical experts, a decision that helped to show that relying on ordinary people with no medical expertise to make medically complicated decisions merely opens the door for misuse and poor decisions.

Second, the statute never requires a determination of what type of sex offender has been charged and convicted and whether they would actually be helped by Depo-Provera. ${ }^{121}$ Therefore, the parolees may be required to take Depo-Provera even if it will not affect his desire or potential to commit another crime. Under this statute, Type I, II, and III sex offenders could be forced to take a drug with a long list of harmful side effects that will in no way deter or affect their potential to commit another sexual offense. ${ }^{122}$ Thus, California may be forcing drugs into a person's body for no real reason.

Third, this statute does not require or even suggest the use of psychological therapy to be used in conjunction with the drug. ${ }^{123}$ Since neither a judge nor the statute can force a parolee to attend therapy, this statute severally limits Depo-Provera's effectiveness, if any, to prevent recidivism among parolee. ${ }^{124}$ This means that parolees, likely to benefit from therapy, are released despite the fact that the absence of therapy increases the risk of recidivism.

Fourth, this statute is flawed in that it fails to establish limits on the duration of Depo-Provera treatments. The statute does provide that treatments shall continue "until the Department of Corrections demonstrates to the Board of Prison Terms that this treatment is no longer necessary." 125 However, it establishes no terms or conditions upon which the Board of Prison Terms can base its determination. Also, charging the Department of Corrections with the job of persuasion could violate our adversarial justice system's underlying principle, that people face an unbiased judge with an advocate on their side before being punished. The Department of Corrections, which is responsible for the sex offender, has an incentive to be very conservative and keep parolees on the drug as long as possible. Since the Department of Corrections and the Board of Prison terms share the same responsibility and interest, they are not going to be as zealous as they should be in trying to get parolees off of Depo-Provera. Thus, instead of making it solely a Department of Corrections' duty, there

120. Id.

121. The opinion of a medical expert could greatly assist the court in making this determination. Given that a determination of sex offender type must be made, it is only logical that medical experts should be required to participate.

122. Fitzgerald, supra note 44, at 1 .

123. Jennifer M. Bund, Comment, Did you Say Chemical Castration?, 59 U. PITT. L. REV. 157, 157 (1997) (This flaw has already been pointed out.).

124. RECIDIVISM FOR SEX OFFENDERS, supra note 1, at 11 (This article contains a study showing substantially lower recidivism rates among sex offenders who underwent therapy as compared to sex offenders who received no treatment at all.).

125. Cal. Penal Code $\S 645$ (1998). 
should be a mechanism through which a parolee can independently or by counsel petition the Board of Prison terms to terminate Depo-Provera treatments.

It is also unclear how long the Department of Corrections can require the sex offender to take Depo-Provera. ${ }^{126}$ What happens when the parole period for the sex offender ends? It is not stated exactly how long the Department of Corrections can require sex offenders to take Depo-Provera injections. For example, can the Department of Corrections decide that the sex offender is still a danger to others and require him to continue to take Depo-Provera injections beyond his parole? If so, then Double Jeopardy rights may be implicated because the criminal justice system is essentially punishing the sex offender beyond the original prison term he was given. ${ }^{127}$

Fifth, another flaw present in the California statute involves the provision relating to the weekly injection of Depo-Provera. The statute requires certain sex offenders be given weekly injections, ${ }^{128}$ but the mechanism and method of providing those injections is not outlined. ${ }^{129}$ Exactly where, when, and how these injections are to be administered to those sex offenders requiring DepoProvera as a condition of parole is unclear. Is the offender supposed to find a facility himself, or will the Department of Corrections handle it? Is the offender to pay for the injections himself, or will the Department of Corrections and the taxpayers pay for the injections of Depo-Provera? Who decides which physician administers the injections? These questions are left unanswered by California's statute.

Finally, the California statute runs afoul of the consent element of the Eighth Amendment. As discussed in Part IV.A.3, in order for consent to be given, it must be voluntary. This statute, however, essentially gives a sex offender three "choices." He can either accept taking Depo-Provera and brave the long list of side-effects, remain in prison for the remainder of his sentence, or undergo a permanent invasive surgical castration.

\section{B. Montana's Chemical Castration Statute}

Montana enacted its chemical castration statute on April 19, 1997, and the statute resembles California's original statute. ${ }^{130}$ The statute states:

(1) A person convicted of a first offense under 45-5503(3), 45-5-503(3), or 45-5-507(4) may, in addition to the sentence imposed under those sections, be sentenced

126. Druhm, supra note 9, at 339-40 (The question of how long a sex offender can be required to take Depo-Provera injections was explored in this Comment.).

127. See discussion supra Part IV.C.

128. CAL. Penal Code $\S 645$ (1998).

129. Druhm, supra note 9, at 340 (The lack of guidelines for providing the DepoProvera injections was examined in this Comment.).

130. Montana Adopts Chemical Castration, S.D. UNION-TriBUTE, Apr. 27, 1997, at A10. 
to undergo medically safe medroxyprogesterone acetate treatment or its chemical equivalent or other medically safe drug treatment that reduces sexual fantasies, sex drive, or both, administered by the department of corrections or its agent pursuant to subsection (4).

(2) A person convicted of a second or subsequent offense under 45-5-502(3), 45-5-503(3), or 45-5-507(4) may, in addition to the sentence imposed under those sections, be sentenced to undergo medially safe medroxyprogesterone acetate treatment or its chemical equivalent or other medically safe drug treatment that reduces sexual fantasies, sex drive, or both, administered by the department of corrections or its agent pursuant to subsection (4).

(3) A person convicted of a first or subsequent offense under 45-5-502, 45-5-503, or 45-5-507 who is not sentenced to medically safe medroxyprogesterone acetate treatment or its chemical equivalent or other medically safe drug treatment that reduces sexual fantasies, sex drive, or both, may voluntarily undergo such treatment, which must be administered by the department of corrections or its agent and paid for by the department of corrections.

(4) Treatment under subsection (1) or (2) must begin one week before release from confinement and must continue until the department of corrections determines that the treatment is no longer necessary. Failure to continue treatment as ordered by the department of corrections constitutes a criminal contempt of court for failure to comply with the sentence, for which the sentencing court shall impose a term of incarceration without possibility of parole of not less than 10 years and not more than 100 years. $^{131}$

This statute is superior to California's statute in that it does not include a mandatory provision for the administration of Depo-Provera to sex offenders; ${ }^{132}$ however, it also shares several of the California statute's weaknesses and has created one of its own.

Montana's statute, while not mandating Depo-Provera treatments, vests the court with discretion to impose Depo-Provera treatments as part of the sen-

131. Mont. Code ANN. § 45-5-512(1)-(4) (1998).

132. CAL. PENAL CODE $\S 645$ (1998) (California's statute mandates drug treatment only for repeat offenders.). 
tence and not merely as a parole condition. ${ }^{133}$ Thus, under the Montana statute, the original trial judge could determine on a first offense that a sex offender would have to take Depo-Provera injections as part of his initial punishment. Since failure to follow the requirement can result in a minimum of an additional decade in prison, the judge can almost impose an additional punishment or a punishment that reverberates beyond his time in prison where a person pays his debt to society. Such an option may be considered cruel and unusual punishment under the Eighth Amendment.

The Montana statute also has a familiar shortcoming in that it does not require, at either the trial or parole stage, input from medical experts. ${ }^{134}$ This means that a person can be medically diagnosed as a sex offender by a lay person such as a judge who lacks medical expertise and who is not subject to the Hippocratic Oath. To allow a judge to essentially diagnose and order treatment with no medical expertise allows for very arbitrary decisions and thus could qualify as cruel and unusual punishment. Also, this determination would be a heavy burden to place on a judge's shoulders and opens the door for a series of forced treatments on prisoners and parolees who should not be required to take Depo-Provera.

Another common problem facing Montana's chemical castration statute is the lack of time limits on mandatory Depo-Provera treatments. Like California, Montana's statute sets no termination date for the Depo-Provera injections. ${ }^{135}$ Instead, the sex offender is required to take the Depo-Provera injections "until the department of corrections determines the treatment is no longer necessary." "136 The statute provides no details for how the Department of Corrections is to make its determination, nor explains whether the sex offender can petition to terminate the Depo-Provera injections. Since a sex offender who fails to continue mandatory Depo-Provera faces ten to one hundred years in jail without the possibility of parole, ${ }^{137}$ the sex offender could decide not to risk that punishment and simply continue to take Depo-Provera instead of fighting to end the injections.

The statute also fails to recognize the distinct types of sex offender. ${ }^{138}$ The four types of sex offender have very subtle, nuanced differences that trained psychologists and psychiatrists are better able to detect than judges. Like the California statute, under the Montana statute, a non-expert judge may be forcing some sex offenders to take a drug with significant side effects but no beneficial effects on their propensity to commit sex crimes. Moreover, it also opens the door for granting parole to Type I, II, and III sex offenders under the

133. Mont. Code ANN. § 45-5-512(1)-(4) (1998).

134. Druhm, supra note 9, at 340 (This comment highlighted this issue in California's chemical castration statute, but the same problem exists with Montana's statute.).

135. MONT. CODE ANN. § 45-5-512 (1998).

136. Id.

137. Id.

138. MONT. CODE ANN. § 45-5-512 (1998). 
mistaken assumption that Depo-Provera would diminish the likelihood that they will commit another sex crime.

\section{Florida's Chemical Castration Statute}

Florida's chemical castration statute was adopted on May $30,1997^{139}$ and designed to go into effect on October $1,1997 .{ }^{140}$ This statute shares many flaws that seem common to most legislatures' efforts to legalize chemical castration. In pertinent part the statute states:

(1) Notwithstanding any other law, the court:

(a) May sentence a defendant to be treated with medroxyprogesterone acetate (MPA), according to a schedule of administration monitored by the Department of Corrections, if the defendant is convicted of sexual battery as described in s. 794.011.

(b) Shall sentence a defendant to be treated with medroxyprogesterone acetate (MPA), according to a schedule of administration monitored by the Department of Corrections, if the defendant is convicted of sexual battery as described in s. 794.011 and the defendant has a prior conviction of sexual battery under s. 794.011.

If the court sentences a defendant to be treated with medroxyprogesterone acetate (MPA), the penalty may not be imposed in lieu of, or reduce, any other penalty prescribed under s. 794.011. However, in lieu of treatment with medroxyprogesterone acetate (MPA), the court may order the defendant to undergo physical castration upon written motion by defendant providing the defendant's intelligent, knowing, and voluntary consent to physical castration as an alternative penalty.

(2)(a) An order of the court sentencing a defendant to medroxyprogesterone acetate (MPA) treatment under subsection (1), shall be contingent upon a determination by a court appointed medical expert, that the defendant is an appropriate candidate for treatment. Such determination is to be made not later than 60 days from the imposition of sentence. Notwithstanding the statutory maximum periods of incarceration as provided in $\mathbf{s}$. 755.082 , an order of the court sentencing a defendant to medroxyprogesterone acetate (MPA) treatment shall 
specify the duration of treatment for a specific term of years, or in the discretion of the court, up to the life of the defendant.

(b) In all cases involving defendants sentenced to a period of incarceration, the administration of treatment with medroxyprogesterone acetate (MPA) shall commence not later than one week prior to defendant's release from prison or other institution. ${ }^{141}$

This statute, like the statutes found in California and Montana, relies heavily on judicial discretion. The judge determines if Depo-Provera is given to a person convicted of a first offense. ${ }^{142}$ On conviction of a second offense, chemical castration becomes mandatory. ${ }^{143}$ However, there is one difference: Section two requires a medical expert to verify that the sex offender could benefit from Depo-Provera, and that the drug would actually be effective. ${ }^{144}$ This is an important difference, as it provides a better system of checks and balances. The statute, however, still has major flaws.

Perhaps the most important flaw in the Florida statute is its failure to provide for the termination of treatment. Unlike statutes in Montana and California, Florida's statute does not provide any way for a person to petition the court or other agencies to end the treatments. The statute simply asks a medical expert to verify that the person could benefit from Depo-Provera. After such verification a judge could, in theory, sentence a person to a lifetime of drug treatments. With no way to stop the drug injections, the defendant could essentially be punished for life beyond the initial prison sentence. In addition, the sex offender may have to take the drugs even though severe side effects result. If a defendant experiences severe side effects or even an allergic reaction, the statute does not provide an opportunity for the offender to cease the injections. This means he would be forced to either continue taking something that seriously affects his health or face punishment for violating the court's proscribed treatment plan.

Another flaw inherent in the Florida statute is that the statute does not provide any form of punishment or response if a person takes other drugs. There are some drugs, such as steroids or possibly Viagra that can counteract the affects of Depo-Provera. ${ }^{145}$ In theory, a person could take such drugs effectively nullifying the impact of chemical castration. ${ }^{146}$ Thus, this statute does not

141. Id.

142. FLa. Stat. ANN. $§ 794.0235(1)$ (a) (West 2006).

143. Fla. Stat. ANN. $\$ 794.0235(1)$ (b) (West 2006).

144. Fla. STAT. ANN. § 794.0235(2)(a) (West 2006).

145. John Litchfield, Sarkozy Acts After Paedophile is Given Viagra, THE INDEPENDENT (Eur.) (Aug. 2007), http://news.independent.co.uk/europe/article2881406.ece (last visited Apr. 9, 2008).

146. Id. 
provide any form of counter measure or enhanced punishment for people who take other drugs to render judge ordered chemical castration ineffective.

Finally, the statute may have constitutional problems with regard to the issue of consent. Under section 1(c), a person can choose surgical castration over chemical castration as a form of treatment. ${ }^{147}$ However, there is still a question of whether a person can knowingly volunteer when the options are prison, mind-altering drugs, or invasive surgery. It is possible that this statute could survive such a challenge, given that the statute specifically states it must be a knowing and voluntary request; but given that people facing this statute have no other viable choices, it may still be argued that one can never knowingly or voluntarily consent to chemical castration.

\section{Louisiana's Chemical Castration Statute}

Louisiana's chemical castration statute is very different from statutes in other states. Louisiana has removed several of the problems inherent in the statutes of other states. Louisiana's efforts, however, are still problematic. The applicable sections of the statute state:

C.(1)(a) No sexual offender, whose offense involved a minor child who is twelve years old or younger; or

(b) Who is convicted two or more times of a violation of R.S. $14: 42,42.1,43,43.1,43.2,43.3,43.4,78,78.1$, or 89.1 shall be eligible for probation, parole, or suspension of sentence or diminution of sentence if imposed as a condition by the sentencing court pursuant to R.S. 15:537(A), unless, as a condition thereof, the offender undergoes a treatment plan based upon a mental health evaluation which plan shall effectively deter recidivist sexual offenses by the offender, thereby reducing risk of reincarceration of the offender and increasing safety of the public, and under which the offender may reenter society. Serial sexual offenders sentenced pursuant to R.S. 15:537(B) shall not be eligible for parole, probation, or suspension of sentence.

(2)(a) 'Mental health evaluation', as used in this Subsection, means an examination by a qualified mental health professional with experience in treating sexual offenders.

(b) The treatment plan may include: 
(i) The utilization of medroxyprogesterone acetate treatment or its chemical equivalent as a preferred method of treatment.

(ii) A component of defined behavioral intervention if the evaluating qualified mental health professional determines that is appropriate for the offender.

(3)(a) The provisions of this Subsection shall only apply if parole, probation, or suspension or diminution of sentence is permitted by law and the offender is otherwise eligible.

(b) If on probation or subject to a sentence that has been suspended, the offender shall begin medroxyprogesterone acetate or chemically equivalent treatment as ordered by the court or a qualified mental health professional and medical staff.

(c) If medroxyprogesterone acetate or chemically equivalent treatment is part of an incarcerated offender's treatment plan, the offender shall begin such treatment six weeks prior to release.

(d) The offender shall continue treatments during incarceration and any suspended sentence, probation, or parole, unless it is determined that the treatment is no longer necessary.

(4) Before beginning medroxyprogesterone acetate or chemical equivalent therapy as required by the provisions of this Subsection, the offender shall be informed about the uses and side effects of medroxyprogesterone therapy, and provide the department with a written acknowledgment that he has received this information.

(5) The offender shall be responsible for the costs of the evaluation, the treatment plan, and the treatment.

(6)(a) Chemical treatment pursuant to this Subsection shall be administered by the state through a licensed medical practitioner.

(b) Any physician or qualified mental health professional who acts in good faith in compliance with this Subsection in the administration of treatment shall be immune from civil or criminal liability for his actions in connection with such treatment.

(7) Failure to continue or complete treatment pursuant to this Subsection shall be a ground for revocation of probation, parole, or suspension of sentence. Good time earned may be forfeited pursuant to R.S. 15:571.4.

(8) If an offender voluntarily undergoes a permanent, surgical alternative to hormonal chemical treatment for 
sex offenders, he shall not be subject to the provisions of this Subsection.

(9) The Department of Public Safety and Corrections shall promulgate rules and regulations to implement the provisions of this Subsection. ${ }^{148}$

Clearly, this statute does significantly improve upon the chemical castrations statutes of California and Florida in one way. Unlike the laws in California or Florida that rely heavily on judicial discretion, Louisiana's statute relies more on medical experts. In the Louisiana statute, Depo-Provera injections are only required when they are part of a treatment program designed and recommended by a "qualified mental health professional [who has] experience interacting with sexual offenders." 149 This provision should keep the state from giving Depo-Provera injections to those sex offenders that will not be helped, and will help target which sex offenders could benefit from Depo-Provera injections more effectively than relying on judicial discretion.

Though this statute is an improvement, it still has several flaws. Perhaps the most significant flaw in this statute is related to funding for Depo-Provera treatment and any other treatment(s) required by this statute. According to this statute, the sex offender is required to pay the costs of the evaluation, the treatment, and the treatment plan. ${ }^{150}$ The statue also requires the sex offender to begin Depo-Provera injections six weeks before release. ${ }^{151}$ There are several problems with these requirements.

First, it is unlikely that most sex offenders requiring Depo-Provera injections are capable of paying for the treatment, as the injections cost hundreds of dollars a month. ${ }^{152}$ According to the statute, a sex offender must find a way to pay for the first six weeks of Depo-Provera treatment while he is still incarcerated in addition to paying for the treatments once released. When a sex offender is released he will likely have difficulty finding a job given he are an exconvict with a sex offense on his record. His prior sexual offense and criminal record severely limits his job pool, since his job must not be within one thousand feet of a secondary or elementary school, day care, playground, private or public youth facility, public swimming pool, or free-standing video arcade facility or he violates his parole and is sent back to prison. ${ }^{153}$ It could take considerable time for a sex offender to locate a job, and yet he still must pay for his treatment and injections. These facts indicate that a large and potentially insurmountable financial burden is placed on the sex offender by this statute. Indeed, if a sex offender does not find a way to pay for Depo-Provera injections

148. LA. REV. STAT. ANN. § 15:538(C)(1)-(9) (1998).

149. LA. REV. STAT. ANN. $\S 15: 538(C)(2)$ (a) (1998).

150. LA. REV. STAT. ANN. § 15:538(C)(5) (1998).

151. LA. REV. STAT. ANN. $\S 15: 538(C)(3)(c)(1998)$.

152. Dispute on Therapy Benefits, supra note 43, at A18.

153. LA. REV. STAT. ANN. § 15:538(D)(1)(a-c) (1998). 
and other treatment(s) ordered by the medical expert, he will be sent back to prison. Given this burden, it is likely that many sex offenders who could qualify and receive the help they need would be unable to pay for such treatment and consequently be stuck in prison. This burden seems to run counter to the purpose of the statute, which is to get sex offenders out of the over-crowded prison while reducing their chances of recidivism.

The second problem with requiring a sex offender to pay for his own Depo-Provera injections and treatment is the determination of when the treatment ends. According to the statute, the sex offender must continue to take DepoProvera injections and pay for his treatment until "it is determined the treatment is no longer necessary." 154 This essentially means that the sex offender has the cost of the Depo-Provera injections and treatment assigned to him by the judicial system, and then must pay for the treatment until the department of corrections determines the treatment is no longer necessary. This is the equivalent of sending someone to prison and then charging them rent. In addition, there is nothing in the statute that indicates that Depo-Provera and any other assigned treatment can end once the parole period for the sex offender is over. The sex offender could be forced to continue treatment beyond his parole period, and if the department of corrections never decides that the treatment is no longer necessary, the sex offender would then be saddled with a financial burden for the rest of his life. This could be considered cruel and unusual punishment.

\section{E. Oregon's Chemical Castration Statute}

Oregon first developed a chemical castration program for sex offenders on July 1, 1999, when a pilot program was ordered by Governor John A. Kitzhaber. ${ }^{155}$ Eventually, a statute was written to deal with sex offenders. In Oregon, a sex offender is defined as a person who:

(a) Has been convicted of a sex crime;

(b) Has been found guilty except for insanity of a sex crime;

(c) Has been found to be within the jurisdiction of the juvenile court for having committed an act that if committed by an adult would constitute a sex crime; or

(d) Is paroled in Oregon under ORS 144.610 after being convicted in another jurisdiction of a crime that would constitute a sex crime if committed in ... [Oregon]. ${ }^{156}$

154. LA. Rev. Stat. ANN. § 15:538(C)(3)(d) (1998).

155. Caroline M. Wong, Comment, Chemical Castration: Oregon's Innovative Approach to Sex Offender Rehabilitation or Unconstitutional Punishment?, 80 OR. L. REV. 267, 274 (2001).

156. OR. REV. STAT. 181.594(5)(a)-(d) (1999). 
With regard to the issue of the chemical castration of sex offenders, statute 144.625 states in pertinent part:

(1) The Department of Corrections shall establish a pilot treatment program for persons convicted of sex crimes who are eligible for parole or post-prison supervision. The purpose of the program is to reduce the risk of reoffending after release on parole or post-prison supervision by providing, each year, 40 to 50 persons convicted of sex crimes with hormone or antiandrogen, such as medroxyprogesterone acetate, treatment.

(2) Under the program the department shall:

(a) Screen persons convicted of sex crimes who are eligible for release within six months on parole or postprison supervision to determine their suitability for hormone or antiandrogen treatment upon release;

(b) Refer persons found most likely to benefit from hormone or antiandrogen treatment to a competent physician for medical evaluation; and

(c) Refer those persons, unless medically contraindicated after the evaluation by a competent physician, to a community physician to begin hormone or antiandrogen treatment upon their release on parole or post-prison supervision.

(3) The State Board of Parole and Post-Prison Supervision shall require as a condition of parole or post-prison supervision hormone or antiandrogen treatment during all or a portion of parole or post-prison supervision of persons required to participate in the hormone or antiandrogen treatment program described in subsection (2) of this section.

(4) A person required to undergo a treatment program under subsection (2) of this section violates a condition of parole or post-prison supervision and is subject to sanctions if the person:

(a) Fails to cooperate in the treatment program required under subsection (2) of this section; or

(b) Takes any steroid or other chemical to counteract the treatment required under subsection (2) of this section. ${ }^{157}$

Though only a pilot program, this is a very well thought out statute. It relies not on judicial discretion, but rather on a competent medical diagnosis and deter- 
mination that the candidate would benefit from Depo-Provera. Also, the statute provides a response should the offender seek to counter Depo-Provera's effects with other drugs. There are, however, two flaws remaining in this statute that create problems.

First, chemical castration can terminate only after a negative evaluation by a competent physician. The evaluation must state that the treatment is either no longer effective, or that it is damaging to the offender. ${ }^{158}$ Moreover, under the Oregon statute, the prisoner cannot refuse to be part of the pilot program, and unlike statutes in other states, Oregon provides no alternative option for the prisoner. ${ }^{159}$ Consequently, unlike his peers in other states, a sex offender in Oregon cannot choose permanent physical castration over drug therapy. Thus, in Oregon, a prisoner either takes the drugs as ordered, or violates parole and returns to prison. ${ }^{160}$

Second, there is an important time gap in this pilot program. DepoProvera takes about a week for the effectiveness of the cycle to begin. ${ }^{161}$ Other states require prisoners to begin treatment one week prior to parole. Oregon, however, gives sex offenders their first treatment after release. ${ }^{162}$ This means for the first week of parole the parolee has his normal sex drive, and may have a motivation to commit a sexual crime. After all, once that one week is up, his hormones will be suppressed and his sex drive greatly diminished. Thus, this week gap represents a last chance to experience normal sexually activity. Another advantage of having a prisoner begin dosages of Depo-Provera before parole is that the Department of Corrections can monitor him during that week. They can check to see if the dosage levels are sufficient and watch for any allergic or negative reactions to the drug. In Oregon, none of that occurs, so the prisoner is released with the hope that the drug will be of sufficient dosage to have some effect, and under the assumption that the former prisoner will not be allergic to or suffer debilitating side effects from the drug.

\section{F. Overall Problems with the Chemical Castration Statutes Now in Effect}

As outlined above, there are no current statutes that have any chance of being both effective and constitutional. In general, however, the statutes can be divided into two major categories based on who determines when DepoProvera applies. Some of the states, such as California and Montana, rely on judicial discretion, and do not require medical experts to weigh in on the administration of Depo-Provera injections to sex offenders. ${ }^{163}$ These same states

158. Id.

159. Id.

160. Id.

161. JoHn MONEY, LOVE AND LOVE SICKNESS: THE SCIENCE OF SEX, GENDER

DIFFERENCE AND PAIR-BONDING 205-207 (1980), http://www.heretical.com/money

/soffence.html (last visited Mar. 15, 2008).

162. OR. REV. STAT. 144.625(2)(c) (1999).

163. Druhm, supra note 9, at 285 (This flaw is first discussed in relation to California's 
also provide little direction for judges when deciding what types of sex offenders will benefit from Depo-Provera. ${ }^{164}$ With no medical input or diagnosis, these statutes fail to adequately handle the use of Depo-Provera.

A second type of statute that seems prevalent is one where the medical community is involved in the original determination of whether a sex offender should receive the Depo-Provera injections. States such as Oregon and Louisiana address the problem of potentially poor identification, of those sex offenders that would benefit from Depo-Provera, by requiring medical diagnosis. However, in these states and statutes, there are flaws with regard to the actual implementation of Depo-Provera injections. These flaws range from financial issues, as in Louisiana where offenders must pay for their own treatment, ${ }^{165}$ to release issues, as in Oregon where offenders do not start treatment until they are released. ${ }^{166}$ Basically then, all state statutes regarding the use of chemical castration are imperfect. Indeed, no state has yet managed to enact a chemical castration statute that is both effective and permissible under the constitution.

\section{G. Europe's Approach to Chemical Castration}

Unlike the United States which has only recently enacted chemical castration statutes, several European countries have had castration statutes on the books for quite some time. Denmark was the first country to create a castration law in $1929 .{ }^{167}$ Sweden passed a castration law in $1944,{ }^{168}$ Finland passed a law in $1970,{ }^{169}$ and Norway enacted its castration law in $1977 .{ }^{170}$ These European statutes are somewhat different from American efforts, in part because the European drafters have greater leeway in drafting their statutes because they are not bound by the United States Constitution and Bill of Rights. The European statutes do, however, provide some insight into the effective design of sex offender statutes.

For example, some the European statutes have a minimum age requirement that must be met before castration becomes an option. ${ }^{171}$ In the United States, age is considered a mitigating factor in several areas of law, ranging from consent to ability to understand. In addition, many states in America have strict statutory rape statutes that define when a sex crime has occurred. Therefore, American States wishing to require the castration of sex offenders should

statute, but it is an applicable flaw here.).

164. See generally Henderson, supra note 27, at 653 (This Note concludes that only certain types of sex offenders can benefit from chemical castration and points out that the California statute does not resolve this issue.).

165. See discussion supra Part IV(d) (discussing the flaw of forcing sex offenders to pay for their own treatment).

166. See discussion supra Part IV(e) (noting that the effects of Depo-Provera wouldn't start until a week after a sex offender has received his first injection).

167. Le Maire, supra note 10, at 294.

168. Svensk Författningssamling, 45 INT'L DIG. HEALTH LEGIS. 324, 324 (1994).

169. Suomen Asetuskokoelma, 21 INT'L Dig. HEALTH LEGIS. 705, 705 (1970).

170. Norsk Lovtidend, 30 INT'L DIG. HEALTH LEGIS. 118, 118 (1979).

171. Russell, supra note 25 , at 442 . 
mirror their European counterparts and adopt a minimum age requirement for the implementation of chemical or physical castration procedures. The exact age of enforcement could be anywhere from fourteen to twenty-one years of age, as long as there is some understanding that a juvenile sex offender younger than a certain age should not be forced to choose between taking a mindaltering medication or facing a longer prison sentence.

Another important factor that distinguishes European sex offender statutes from their American counterparts is that many European statutes place greater emphasis on medical expert testimony and diagnosis; rather, than relying primarily on judicial discretion. Several European statutes require a neutral medical expert board to make a determination on whether the sex offender would even benefit from castration before it is considered as an option. Given that a majority of American judges have no medical background or experience, the European reliance on medical experts should also be considered by American legislatures when drafting sex offender statutes. Indeed, an increased reliance on the judgment of medical practitioners could only enhance the efficacy and constitutionality of American sex offender statutes.

\section{CONCLUSION}

Castration has been a form of punishment for centuries in the most brutal of societies. It was even endorsed as an effective eugenics tool by such noted historical figures as Adolf Hitler. The latest form of state-sanctioned castration to appear in society is chemical castration. The use of Depo-Provera injections as a form of chemical castration is a concept that has recently been considered a potentially effective way to handle sex offenders in the United States. The concept of chemical castration does, however, raise several constitutional issues, ranging from cruel and unusual punishment to the violation of equal protection. Even if chemical castration could survive these myriad constitutional attacks, states have thus far been unable to create statutes without major flaws.

The use of Depo-Provera may have a place within the psychiatric community to help cure some sexual disorders, but the judicial system should not make it a condition of parole. Indeed, if chemical castration is to be considered a viable option in the United States, prisons should provide psychological treatment, in conjunction with drug therapy, while a prisoner is in custody. This combination of services could potentially resolve a significant portion of the sex offender recidivism problem facing the states. Moreover, if states are going to continue relying on statutorily mandated castration to resolve the problems surrounding the rerelease of sex offenders and overcrowding, the drafting legislatures should look to the European legal system for effective methods of implementing and monitoring such programs. Baring these changes, the mandated castration of sex offenders in the United States should be stopped. Indeed, castrating sex offenders just simply because they might commit another sex crime should no longer be regarded as an expedient way to create desper- 
ately needed jail space. Rather, state legislatures and the judiciary should regard chemical castration by Depo-Provera as a treatment, not a punishment. 